\title{
The effect of different dietary fibres on microbial population and short-chain fatty acid concentration in the caecum of pigs
}

\author{
I. Furgal-Dierżuk ${ }^{1}$ \\ National Research Institute of Animal Production, \\ Department of Animal Nutrition \\ 32-083 Balice, Poland
}

\begin{abstract}
The effects of different dietary fibre (Arbocel R, Vitacel AF, guar gum) on caecal short-chain fatty acid (SCFA) concentrations, caecal total weight, $\mathrm{pH}$ and bacterial populations were evaluated on 24 growing-finishing pigs. The concentrations of acetic, propionic, butyric acid and total SCFA were significantly $(\mathrm{P} \leq 0.05)$ higher in the guar gum group compared with the other groups. Caecal tissue weight increased with the guar gum diet.
\end{abstract}

KEY WORDS: pig, fibre, caecum, bacteria, SCFA

\section{INTRODUCTION}

Diet has an important influence on gut morphology and function, including effects on proliferation of pathogenic bacteria, and can provide either beneficial or harmful input (Montagne et al., 2003). Dietary fibre (DF) is a dietary component that has a major influence in this regard. The term "dietary fibre" is commonly defined as plant material that resists digestion by the secreted enzymes of the human and monogastric animal alimentary tracts, but which may be fermented by microflora in the distal part of the gut. The physiological and protective effects against a range of many diseases are dependent on a complex mixture of structural, chemical and physical properties of dietary fibre (water-holding capacity, viscosity, gel formation, fermentation and bile acid binding). Soluble fibres are more easily fermented in the large intestine to short-chain fatty acids (SCFA) as compared with cellulose; propionic acid produced here may lower

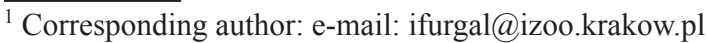


hepatic cholesterol synthesis (Demigne et al., 1995), butyrate has a role in cancer prevention (Hass et al., 1997). Pectin, guar gum, oat gum or inulin have been found to have protective effects against colonization of digestive tract epithelium by pathogenic bacteria (Bengmark et al., 1998).

The aim of this study was to evaluate the influence of different dietary fibres on the concentration of SCFA in the caecum of pigs and populations of Lactobacillus spp. and Escherichia coli.

\section{MATERIAL AND METHODS}

The experiment was performed on 24 growing-finishing pigs (Landrace $\times$ Large White sows mated to a Duroc $\times$ Pietrain) from 60 to $110 \mathrm{~kg}$ body weight. The animals were divided into 3 groups of 8 animals ( 4 barrows and 4 gilts) and housed individually in steel cages. Feed and water were provided ad libitum. The basal diet contained, \%: ground barley 50.8, ground triticale 24.5 , soyabean meal 17 , rapeseed oil 2, L-lysine 0.04, Lutamix PT-2 0.5, NaCl 0.2, dicalcium phosphate 1.2, fodder limestone 0.3. The diet was isoenergetic, isoproteinous and isofibrous (12.8 MJ ME, 16\% crude protein, $4 \%$ crude fibre), AOAC (1990). To the basal diet was added $3.5 \%$ of one of the following kinds of fibre: Arbocel R(cellulose+lignin, from J. Rettenmaier and Söhne GMBH + CO, Germany), Vitacel AF (cellulose+apple pectin, J. Rettenmaier and Söhne GMBH + CO, Germany ) and guar gum (Habgen Guars Ltd.)

All of the pigs were slaughtered at the end of the experiment. The caecum with its contents was weighed to determine total weight. The $\mathrm{pH}$ of the caecal contents was measured using a CP-411 pH meter with a Metron OSH 12-01 electrode. The caecal content was transferred to microfuge tubes, preserved with $25 \%$ meta-phosphoric acid and immediately frozen at $-20^{\circ} \mathrm{C}$. The content of SCFA (propionic, acetic, butyric) in the caecum was measured using a Varian 3400 gas chromatograph (CP-WAX 58 column, $0.53 \mathrm{~mm} \times 25 \mathrm{~m}$ ). The caecal content was stored under liquid nitrogen for later microbiota enumeration (Lactobacillus spp. on Rogosa SL agar and Escherichia coli on CPS ID 2 agar). Data were analysed by ANOVA using the GLM procedure of SAS (1992).

\section{RESULTS}

The influence of dietary fibre on the short-chain fatty acid concentration in the caecum is given in Table 1. The concentrations of acetic, propionic, butyric acids and total SCFA were significantly $(\mathrm{P} \leq 0.05)$ higher in the guar gum group when compared with the Vitacel AF and Arbocel R groups. Total caecum weight, $\mathrm{pH}$ Lactobacillus spp. and Escherischia coli counts in caecum contents were similar in all groups. An elevation was noted in caecal tissue weight with the guar gum 
diet. Caecal E. coli concentrations were lower $(\mathrm{P} \leq 0.05)$ in gilts compared with barrows.

\section{DISCUSSION}

DF in diets for non-ruminant animals seem to be beneficial for gut health (Williams et al., 2001). DF modulates gut health by complex interactions with the gut epithelium, mucus and microflora.

Table 1. Effect of dietary fibre on short-chain fatty acid concentration, $\mathrm{pH}$ and bacteria counts in the caecum of pigs

\begin{tabular}{|c|c|c|c|c|c|c|c|}
\hline \multirow[b]{2}{*}{ Item } & \multicolumn{3}{|c|}{ Dietary fibre (DF) } & \multicolumn{2}{|c|}{$\operatorname{Sex}(\mathrm{S})$} & \multirow{2}{*}{ SEM } & \multirow{2}{*}{$\mathrm{DF} \times \mathrm{S}$} \\
\hline & Arbocel R & Vitacel AF & guar gum & gilts & barrows & & \\
\hline \multicolumn{8}{|c|}{ Short-chain fatty acid, $\mu \mathrm{mol} / \mathrm{g}$ caecum } \\
\hline acetic & $68.4^{\mathrm{b}}$ & $70.0^{\mathrm{b}}$ & $79.1^{\mathrm{a}}$ & 71.6 & 73.5 & 1.33 & ns \\
\hline propionic & $31.8^{\mathrm{b}}$ & $28.9^{\mathrm{b}}$ & $43.5^{\mathrm{a}}$ & 33.0 & 36.4 & 0.94 & ns \\
\hline butyric & $15.9^{\mathrm{b}}$ & $14.6^{\mathrm{b}}$ & $19.9^{\mathrm{a}}$ & 17.2 & 16.5 & 0.42 & ns \\
\hline total SCFA & $120.7^{\mathrm{b}}$ & $116.9^{\mathrm{b}}$ & $145.5^{\mathrm{a}}$ & 125.5 & 129.9 & 3.10 & ns \\
\hline \multicolumn{8}{|l|}{ Саecum } \\
\hline content $\mathrm{pH}$ & 5.8 & 6.0 & 5.9 & 6.0 & 5.9 & 0.04 & ** \\
\hline total weight, g & 571 & 649 & 636 & 607 & 630 & 0.03 & ns \\
\hline tissues weight, $\mathrm{g}$ & $143^{\mathrm{b}}$ & $139^{\mathrm{b}}$ & $182^{\mathrm{a}}$ & 144 & 166 & 4.80 & ns \\
\hline \multicolumn{8}{|c|}{ Bacteria counts, $\log _{10} \mathrm{CFU} / \mathrm{g}$ caecum } \\
\hline Lactobacillus spp. & 9.4 & 8.9 & 8.9 & 8.8 & 9.2 & 0.75 & ns \\
\hline Escherichia coli & 5.4 & 5.5 & 5.7 & $5.2^{\mathrm{b}}$ & $5.9^{\mathrm{a}}$ & 0.10 & ns \\
\hline
\end{tabular}

Soluble DF is generally more easily, rapidly and completely fermented as it arrives in the large intestine than is insoluble DF (Nyman et al., 1986). In the present study, caecal total SCFA, acetate, propionate and butyrate contents were increased in the guar group compared with the Arbocel R and Vitacel AF groups. Similar effects were demonstrated in rats (Levrat et al., 1996). The elevation noted in caecal tissue weight with the guar gum diet may result from SCFA normalizing cell proliferation. Butyrate influences the development and growth of the large and small intestine by stimulating epithelial cell proliferation and crypt depth in the large intestine (Sakata et al., 2001). In present study, the $\mathrm{pH}$ values in all groups were similar $(\sim 5.9)$. Low $\mathrm{pH}$ values $(6.02)$ were observed in rats fed guar gum (Levrat et al., 1996). The population of coliform bacteria, which was closely related to the $\mathrm{pH}$, can be lowered in a low-pH environment. DF such as pectin, guar gum, oat gum have putative protective effects against colonization by pathogenic bacteria (E. coli) in humans (Bengmark et al., 1998) and in pigs (May et al., 1994). In the present study, a high level of Lactobacillus spp., was observed in all pigs, similar effects were demonstrated in rats (Levrat et al., 1996). 


\section{CONCLUSIONS}

The results of the study indicated that the beneficial effect of guar gum on gut health is more distinct in comparison with cellulose+lignin (Arbocel R) and cellulose+apple pectin (Vitacel AF).

\section{REFERENCES}

AOAC, 1990. Official Methods of Analysis, Association of Official Analytical Chemists. $15^{\text {th }}$ Edition. Arlington VA

Bengmark S., 1998. Immunnutrition - role of biosurfactants, fiber, and probiotic bacteria. Nutrition $14,585-594$

Demigné Ch., Morand C., Levrat M. A., Besson C., Rémésy Ch., 1995. Effect of propionate on fatty acids and cholesterol synthesis and on acetate metabolism in isolated rat hepatocytes. Brit. J. Nutr. 74, 209-219

Hass R., Busche R., Luciano L., Reale E., Engelhard W.V., 1997. Lack of butyrate is associated with induction of Bax and subsequent apoptosis in the proximal colon of guinea pig. Gastroenterology $112,875-881$

Levrat M.A., Moundras C., Younes H., Morand Ch., Demigne Ch., Remesy Ch., 1996. Effectiveness of resistant starch, compared to guar gum, in depressing plasma cholesterol and enhancing fecal steroid excretion. Lipids 31, 1069-1075

May T., Mackie R.I., Fahey G.C., Cremin J.C., Garleb K.L., 1994. Effect of fiber source on shortchain fatty acid production and on the growth and toxin production by Clostridium difficile. Scand. J. Gastroenterol. 29, 916-922

Montagne M., Pluske J.R., Hampson D.J., 2003. A review of interactions between dietary fibre and the intestinal mucosa, and their consequences on digestive health in young non-ruminant animals. Anim. Feed Sci. Tech. 108, 95-117

Nyman M., Asp N.G., Cumming J., Wiggins H., 1986. Fermentation of dietary fibre in the intestinal tract. A comparison between man and rat. Brit. J. Nutr. 55, 487-496

Williams B.A., Verstegen M.W., Tamminga S., 2001. Fermentation in the large intestine of singlestomached animals and its relationship to animal health. Nutr. Res. Rev. 14, 207-227

Sakata T., Inagaki M., 2001. Organic acid production in the large intestine: implication for epithelial cell proliferation and cell death. In: A. Piva, K.E. Bach Knudsen, J.E. Lindberg (Editors). The Gut Environment of Pigs. Nottingham University Press, Nottingham, pp. 85-94

\section{STRESZCZENIE}

\section{Wpływ różnych rodzajów włókna pokarmowego na populację bakterii i koncentrację krótkołańcuchowych lotnych kwasów tluszczowych w jelicie ślepym świń}

W doświadczeniu przeprowadzonym na 24 tucznikach badano wpływ różnych rodzajów włókna pokarmowego dodanego do diety (Arbocel R, Vitacel AF, guma guarowa) na produkcję krótkołańcuchowych lotnych kwasów tłuszczowych w jelicie ślepym, masę jelita, pH i populację bakterii jelita ślepego.

Poziom kwasu octowego, propionowego, masłowego oraz poziom SCFA był istotnie $(\mathrm{P} \leq 0,05)$ wyższy w grupie z gumą guarową w porównaniu z pozostałymi grupami. Stwierdzono wzrost masy tkanek jelita ślepego w grupie z gumą guarową. 